Zeszyty Naukowe Szkoły Głównej Gospodarstwa Wiejskiego

Ekonomika i Organizacja Gospodarki Żywnościowej nr 120, 2017: 97-109

DOI 10.22630/EIOGZ.2017.120.41

Irena Ozimek

Wydział Nauk Ekonomicznych

Szkoła Główna Gospodarstwa Wiejskiego w Warszawie

Julita Szlachciuk, Natalia Przeździecka-Czyżewska

Wydział Nauk o Żywieniu Człowieka i Konsumpcji

Szkoła Główna Gospodarstwa Wiejskiego w Warszawie

\title{
Zafałszowania artykułów rolno-spożywczych w świetle regulacji prawnych oraz działań organów urzędowej kontroli żywności w Polsce
}

\section{Wstęp}

W 2016 roku, podobnie jak w latach ubiegłych, największy udział w strukturze wydatków ogółu polskich gospodarstw domowych miały wydatki na żywność i napoje bezalkoholowe $-24,2 \%$, przy czym w gospodarstwach pracujących na własny rachunek stanowiły one $20,9 \%$, a w gospodarstwach rolników - 31,5\% wszystkich wydatków [GUS 2017]. Z uwagi więc na znaczący nadal udział wydatków na żywność w strukturze wydatków ogółem ważna jest kwestia jakości i bezpieczeństwa żywności oferowanej w sprzedaży. Potwierdzenie autentyczności rodzajowej i gatunkowej produktu, jak również wykrywanie zafałszowań jest zwykle trudne, pracochłonne i kosztowne. Szybki rozwój technik analitycznych pozwala już na identyfikację i ilościowe oznaczenie nawet śladowych ilości wielu składników. Postęp techniczny zwiększa jednak także możliwości fałszowania żywności [Targoński i Stój 2005, UOKiK 2010]. Jak podkreślają Targoński i Stój [2005], wykrywanie zafałszowań żywności jest trudne $\mathrm{z}$ uwagi na coraz bardziej wyrafinowane metody zafałszowań, jak i na stosowanie coraz bardziej wyrafinowanych technik detekcji.

$\mathrm{Na}$ fałszowaniu żywności korzystają nieuczciwi przedsiębiorcy, a tracą konsumenci, gdyż nabywają produkt niepełnowartościowy, czasami wręcz nienadający się do spożycia. Dlatego też badanie tożsamości (autentyczności) w kontekście nazwy, pod jaką jest produkt oferowany i weryfikacja składu podanego na 
opakowaniu ze stanem faktycznym, stanowi podstawę zapewnienia właściwej jakości żywności. Biorąc to pod uwagę, organy urzędowej kontroli żywności (Inspekcja Jakości Handlowej Artykułów Rolno-Spożywczych oraz Inspekcja Handlowa), w zależności od swoich uprawnień prowadzą w różnych miejscach produkcji lub wprowadzania do obrotu kontrole, których celem jest sprawdzanie, czy oferowana konsumentom żywność nie jest zafałszowana, czyli, czy do produktów spożywczych nie wprowadza się zmian, których celem jest ukrycie rzeczywistego ich składu lub innych właściwości albo stosowanie nazw rodzajowych nieadekwatnych do surowców i zastosowanych procesów technologicznych, a przez to naruszenie interesu ,słabszych" uczestników rynku [UOKiK 2010, IJHARS 2017a].

Jak podkreśla Kowalczyk [2014a], sposoby fałszowania żywności są zróżnicowane w zależności od grupy produktowej oraz czasu analizy. To drugie kryterium jest konsekwencją postępu technicznego w produkcji żywności i dostępnych w związku z tym metod wytwarzania i jej fałszowania. Jedne i drugie zmieniają się wraz z upływem czasu. Fałszowanie żywności ma lub może mieć wiele konsekwencji: ekonomiczne, fiskalne, zdrowotne, społeczne, rynkowe, międzynarodowe, etyczne [Kowalczyk 2009]. Już w połowie XIX wieku Hassall dokonał podziału wszystkich form fałszowania żywności na trzy grupy w zależności od celu ich użycia, w tym: zwiększające ilość i masę towaru, barwiące oraz korygujące zapach, smak, a także inne cechy wyrobu. Stąd też cel fałszowania żywności w rezultacie nie uległ zmianie od dawna [Kowalczyk 2014a].

\section{Materiał i metodyka}

Celem badań było przedstawienie regulacji prawnych, zarówno polskich, jak i unijnych, dotyczących zafałszowań artykułów rolno-spożywczych oraz analiza wyników działań Inspekcji Jakości Handlowej Artykułów Rolno-Spożywczych (IJHARS) w kontekście upublicznionych decyzji obejmujących tego rodzaju zafałszowania. W celu zrealizowania podjętego celu badań dokonano analizy danych wtórnych, tj. aktów prawnych oraz wydanych w latach 2009-2017 (I półrocze) przez IJHARS decyzji dotyczących zafałszowań artykułów rolno-spożywczych, wydanych na podstawie art. 29 oraz art. 40a ust. 1 pkt 4 ustawy o jakości handlowej artykułów rolno-spożywczych, które zostały podane do publicznej wiadomości. Analizy dokonano na podstawie podziału zafałszowań ze względu na grupę technologiczną artykułów rolno-spożywczych, województwo oraz rok ich występowania. Uwzględniono także stworzony na potrzeby niniejszego artykułu podział ze względu na przyczynę zafałszowania. W przypadku jednej grupy technologicznej każdą przyczynę traktowano jak odrębne zgłoszenie. 


\section{Wybrane regulacje prawne dotyczące zafałszowań artykułów rolno-spożywczych}

Zgodnie z najważniejszym aktem prawnym z zakresu prawa żywnościowego w Unii Europejskiej, tj. rozporządzeniem (WE) 178/2002 Parlamentu Europejskiego i Rady (WE) z dnia 28 stycznia 2002 roku ustanawiającym ogólne zasady i wymagania prawa żywnościowego, powołującym Europejski Urząd ds. Bezpieczeństwa Żywności oraz ustanawiającym procedury w zakresie bezpieczeństwa żywności, prawo żywnościowe ma na celu ochronę interesów konsumentów i powinno stanowić podstawę dokonywania przez konsumentów świadomego wyboru związanego ze spożywaną przez nich żywnością. Ponadto ma ono na celu zapobieganie oszukańczym lub podstępnym praktykom, fałszowaniu żywności oraz wszelkim innym praktykom mogącym wprowadzać konsumenta w błąd. Ponadto w Polsce, zgodnie z art. 76 Konstytucji Rzeczypospolitej Polskiej z dnia 2 kwietnia 1997 roku, władze publiczne chronią konsumentów przed działaniami zagrażającymi ich zdrowiu oraz przed nieuczciwymi praktykami rynkowymi.

W ustawie z dnia 21 grudnia 2000 roku o jakości handlowej artykułów rolno-spożywczych zdefiniowano pojęcie ,artykuły rolno-spożywcze” jako produkty rolne, runo leśne, dziczyznę, organizmy morskie i słodkowodne w postaci surowców, półproduktów oraz wyrobów gotowych otrzymywanych z tych surowców i półproduktów, w tym środki spożywcze. W ustawie też zawarta została definicja „artykułu rolno-spożywczego zafałszowanego” oraz obowiązek upublicznienia informacji o przedsiębiorstwach fałszujących tego rodzaju artykuły. Zgodnie z tą ustawą ,,artykuł rolno-spożywczy zafałszowany” to „produkt, którego skład jest niezgodny z przepisami dotyczącymi jakości handlowej poszczególnych artykułów rolno-spożywczych, albo produkt, w którym zostały wprowadzone zmiany, w tym zmiany dotyczące oznakowania, mające na celu ukrycie jego rzeczywistego składu lub innych właściwości, jeżeli niezgodności te lub zmiany w istotny sposób naruszają interesy konsumentów finalnych". W szczególności dotyczy to następujących sytuacji, jeżeli:

„a) dokonano zabiegów, które zmieniły lub ukryły jego rzeczywisty skład lub nadały mu wygląd produktu zgodnego z przepisami dotyczącymi jakości handlowej,

b) w oznakowaniu podano nazwę niezgodną z przepisami dotyczącymi jakości handlowej poszczególnych artykułów rolno-spożywczych albo niezgodną z prawda, 
c) w oznakowaniu podano niezgodne z prawdą dane w zakresie składu, pochodzenia, terminu przydatności do spożycia lub daty minimalnej trwałości, zawartości netto lub klasy jakości handlowej”.

Czynności podejmowane przez IJHARS mają na celu eliminowanie z rynku produktów niespełniających wymagań określonych w przepisach lub zadeklarowanych przez producentów w zakresie jakości handlowej artykułów rolno-spożywczych. Ponadto istotnym aspektem działalności IJHARS jest przeciwdziałanie wprowadzaniu do obrotu produktów zafałszowanych. Działania IJHARS w zakresie wykrywania zafałszowań obejmują sprawdzenie parametrów fizykochemicznych mających na celu skontrolowanie zgodności składu produktu $\mathrm{z}$ określonymi wymaganiami w zakresie jakości handlowej oraz deklaracją producenta. Obejmują one także znakowanie żywności. Informacje zawarte w decyzjach, dotyczące zafałszowania artykułów rolno-spożywczych, podaje się zgodnie z art. 29 ustawy z dnia 21 grudnia 2000 roku o jakości handlowej artykułów rolno-spożywczych do publicznej wiadomości, z pominięciem informacji stanowiących tajemnicę przedsiębiorstwa oraz inne tajemnice podlegające ochronie na podstawie przepisów odrębnych oraz na mocy art. 40 ust. 1 pkt 4 tej ustawy (wprowadzanie do obrotu artykułów rolno-spożywczych zafałszowanych, podlega karze pieniężnej w wysokości nie wyższej niż 10\% przychodu osiągniętego w roku rozliczeniowym poprzedzającym rok nałożenia kary, nie niższej jednak niż 1000 zł).

W celu uzyskania wysokiego poziomu ochrony zdrowia konsumentów i zagwarantowania im prawa do informacji należy zapewnić odpowiednie informowanie konsumentów na temat spożywanej przez nich żywności. Stąd też taką rolę spełnia rozporządzenie Parlamentu Europejskiego i Rady (UE) 1169/2011 z dnia 25 października 2011 roku dotyczące przekazywania konsumentom informacji na temat żywności. Przyczyną wprowadzenia tej regulacji była konieczność aktualizacji, uproszczenia i ujednolicenia prawa żywnościowego UE dotyczącego znakowania żywności w zakresie wymagań ogólnych, a także wymagań dotyczących podawania informacji o wartości odżywczej. Zgodnie z tym rozporządzeniem między innymi informacje na temat żywności muszą być rzetelne, jasne i łatwe do zrozumienia dla konsumenta, a etykiety żywności powinny być jasne i zrozumiałe, aby były pomocne dla konsumentów, którzy chcą dokonywać bardziej świadomych wyborów dotyczących żywności. W tym akcie prawnym uwzględniono wszystkie aspekty dotyczące czytelności, w tym czcionkę, kolor $\mathrm{i}$ kontrast. Ponadto w tym unijnym rozporządzeniu zwrócono uwagę, że informacje na temat żywności nie mogą wprowadzać w błąd, w szczególności:

a) co do właściwości środka spożywczego, a w szczególności co do jego charakteru, tożsamości, właściwości, składu, ilości, trwałości, kraju lub miejsca pochodzenia, metod wytwarzania lub produkcji; 
b) przez przypisywanie środkowi spożywczemu działania lub właściwości, których on nie posiada;

c) przez sugerowanie, że środek spożywczy ma szczególne właściwości, gdy w rzeczywistości wszystkie podobne środki spożywcze mają takie właściwości, zwłaszcza przez szczególne podkreślanie obecności lub braku określonych składników lub składników odżywczych;

d) przez sugerowanie poprzez wygląd, opis lub prezentacje graficzne, że chodzi o określony środek spożywczy lub składnik, mimo że w rzeczywistości komponent czy składnik naturalnie obecny lub zwykle stosowany w danym środku spożywczym został zastapiony innym komponentem bądź innym składnikiem.

Definicja odnosząca się już tylko do zafałszowań żywności zawarta jest również w ustawie z dnia 25 sierpnia 2006 roku o bezpieczeństwie żywności i żywienia, zgodnie z którą ,środek spożywczy zafałszowany”, to środek, którego skład lub inne właściwości zostały zmienione, przy czym konsument nie został o tym poinformowany $\mathrm{w}$ sposób określony w przepisach rozporządzenia (UE) 1169/2011 z dnia 25 października 2011 roku w sprawie informowania konsumentów o żywności, albo środek spożywczy, w którym zostały wprowadzone zmiany mające na celu ukrycie jego rzeczywistego składu lub innych właściwości. Środek spożywczy jest ,środkiem spożywczym zafałszowanym, w szczególności jeżeli:

a) dodano do niego substancje zmieniające jego skład lub obniżające jego wartość odżywczą,

b) odjęto składnik bądź zmniejszono zawartość jednego lub kilku składników decydujących o wartości odżywczej czy innej właściwości środka spożywczego,

c) dokonano zabiegów, które ukryły jego rzeczywisty skład lub nadały mu wygląd środka spożywczego o należytej jakości,

d) niezgodnie z prawdą podano jego nazwę, skład, datę lub miejsce produkcji, termin przydatności do spożycia lub datę minimalnej trwałości albo w inny sposób nieprawidłowo go oznakowano - wpływając przez te działania na bezpieczeństwo środka spożywczego".

Należy podkreślić, że walka z oszustwami w branży spożywczej jest priorytetem UE, którego celem jest utrzymanie najwyższych standardów bezpieczeństwa żywności. Nie istnieje jednak zharmonizowana unijna definicja oszustwa w branży spożywczej. Brak zharmonizowanej definicji nie uniemożliwia jednak Komisji Europejskiej i państwom UE podejmowania skoordynowanych działań przeciwko „nieuczciwym praktykom” w łańcuchu dostaw żywności. Powszechnie przyjmuje się, że oszustwa w branży spożywczej obejmują przypadki, w których dochodzi do naruszenia unijnego prawa żywnościowego, którego 
celem jest dążenie do osiagnięcia korzyści gospodarczej lub finansowej poprzez wprowadzenie w błąd konsumentów. Prawo żywnościowe na poziomie unijnym jest w znacznej mierze zharmonizowane, ujednolicenie dotyczy jednak głównie prawa żywnościowego materialnego. Procedury postępowania w przypadku wykrycia naruszeń prawa żywnościowego materialnego, w tym przede wszystkim wymierzane sankcje administracyjne, znacznie różnią się między poszczególnymi krajami UE. Rozbudowanie łańcucha żywnościowego, w szczególności znaczna liczba pośredników, których siedziby są nierzadko zlokalizowane w wielu państwach członkowskich UE, dodatkowo utrudniają kontrole, a przede wszystkim dotarcie do podmiotu fałszującego żywność. Stąd też pojawiła się inicjatywa mająca na celu wzmocnienie systemu kontroli UE jako całości w zakresie wykrywania oszustw w łańcuchu żywnościowym i przeciwdziałania im. W dniu 8 lipca 2013 roku Komisja Europejska wraz z państwami członkowskimi utworzyła grupę roboczą ds. oszustw związanych z żywnością [PFPŻ ZP 2017]. Usprawnieniem transgranicznej pomocy administracyjnej i współpracy zajmuje się obecnie unijna sieć ds. oszustw w branży spożywczej - EU Food Fraud Network (FFN), złożona z przedstawicieli Komisji Europejskiej, wszystkich krajów UE oraz Szwajcarii, Norwegii i Islandii [EC 2016]. W dniu 18 listopada 2015 roku został uruchomiony unijny system Administrative Assistance and Cooperation (AAC), za pomocą którego państwa członkowskie przekazują sobie wzajemnie informacje na temat stwierdzonych nieprawidłowości. Należy też wspomnieć, że funkcjonowanie tego systemu związane jest z zasadami funkcjonowania pomocy administracyjnej i współpracy określonymi w decyzji wykonawczej Komisji (UE) 2015/1918 z dnia 22 października 2015 roku ustanawiającej system pomocy i współpracy administracyjnej na podstawie rozporządzenia (WE) 882/2004 Parlamentu Europejskiego i Rady w sprawie kontroli urzędowych przeprowadzanych w celu sprawdzenia zgodności z prawem paszowym i żywnościowym oraz regułami dotyczącymi zdrowia zwierząt i dobrostanu zwierząt. W latach 2015-2016 zidentyfikowano w ramach unijnego sytemu około 300 oszustw na poziomie UE [EC 2016].

Decyzją ministra rolnictwa i rozwoju wsi główny inspektorat jakości handlowej artykułów rolno-spożywczych został wyznaczony jako krajowy punkt kontaktowy ds. oszustw żywnościowych dla Polski [IJHARS 2017a]. Każdorazowo po otrzymaniu zgłoszenia IJHARS zleca kontrolę przedsiębiorstwa, którego zgłoszenie dotyczy, oraz dokłada wszelkich starań w celu wyjaśnienia zaistniałych nieprawidłowości.

Warto również nadmienić, że w dniu 27 kwietnia 2017 roku weszło w życie rozporządzenie Parlamentu Europejskiego i Rady (UE) 2017/625 z dnia 15 marca 2017 roku w sprawie kontroli urzędowych i innych czynności urzędowych przeprowadzanych $\mathrm{w}$ celu zapewnienia stosowania prawa żywnościowego 
i paszowego oraz zasad dotyczących zdrowia i dobrostanu zwierząt, zdrowia roślin i środków ochrony roślin ${ }^{1}$. Spowoduje to zmiany w zakresie funkcjonowania organów urzędowych żywności.

\section{Upublicznione decyzje IJHARS w zakresie zafałszowanych artykułów rolno-spożywczych}

Zadaniem Inspekcji Jakości Handlowej Artykułów Rolno-Spożywczych jest przede wszystkim ochrona konsumentów i producentów poprzez zapewnienie dostępu do rzetelnych informacji na temat artykułów rolno-spożywczych oraz przeciwdziałanie nieuczciwym praktykom rynkowym. Jak wspomniano wcześniej, decyzje dotyczące zafałszowań artykułów rolno-spożywczych, wydane na podstawie art. 29 oraz art. 40a ust. 1 pkt 4 ustawy z 2000 roku o jakości handlowej artykułów rolno-spożywczych, są upubliczniane [IJHARS 2017b].

W badanym okresie (od 2009 r. do I półrocza 2017 r.) upubliczniono najwięcej decyzji dotyczących zafałszowań artykułów rolno-spożywczych w województwach małopolskim oraz zachodniopomorskim. Najmniej tego typu sytuacji odnotowano w województwach opolskim oraz łódzkim (tab. 1).

Tabela 1

Liczba upublicznionych decyzji dotyczących zafałszowań artykułów rolno-spożywczych wydanych w latach 2009-2017 z uwzględnieniem województw*

\begin{tabular}{|c|c|c|c|c|c|c|c|c|c|c|}
\hline Województwo & $\begin{array}{l}\frac{E}{\Phi} \\
\stackrel{0}{\circ} \\
O \\
O\end{array}$ & 尺̊ & 웅 & ז & $\stackrel{N}{\circ}$ & $\stackrel{m}{\circ}$ & $\stackrel{+}{\grave{N}}$ & $\stackrel{10}{\stackrel{2}{N}}$ & $\stackrel{0}{\circ}$ & 동 \\
\hline 1 & 2 & 3 & 4 & 5 & 6 & 7 & 8 & 9 & 10 & 11 \\
\hline Dolnośląskie & 36 & - & - & 3 & 7 & - & 9 & 4 & 11 & 2 \\
\hline $\begin{array}{l}\text { Kujawsko- } \\
\text {-pomorskie }\end{array}$ & 31 & 4 & 10 & - & 1 & 13 & 3 & - & - & - \\
\hline Lubelskie & 57 & 2 & 10 & 9 & 6 & 1 & 2 & 3 & 11 & 13 \\
\hline Lubuskie & 57 & 3 & 12 & 1 & 5 & 1 & 5 & 6 & 17 & 7 \\
\hline Łódzkie & 20 & - & - & - & - & 3 & 2 & 5 & 8 & 2 \\
\hline Opolskie & 7 & - & - & - & - & - & - & - & 7 & - \\
\hline Małopolskie & 136 & 10 & 9 & 16 & 14 & 6 & 3 & 13 & 53 & 12 \\
\hline Mazowieckie & 51 & 1 & - & 1 & 2 & 11 & 2 & 3 & 24 & 7 \\
\hline Podkarpackie & 24 & 2 & 4 & 2 & 3 & - & - & - & 6 & 7 \\
\hline Podlaskie & 29 & 3 & 2 & - & 6 & - & 3 & - & 15 & - \\
\hline
\end{tabular}
${ }^{1}$ Rozporządzenie to generalnie będzie stosowane dopiero od 14 grudnia 2019 roku, a niektóre wyraźnie
wskazane przepisy od 28 kwietnia 2018 lub od 29 kwietnia 2022 roku (art. 167). 
Tabela 1, cd.

\begin{tabular}{|l|c|c|c|c|c|c|c|c|c|c|}
\hline \multicolumn{1}{|c|}{1} & 2 & 3 & 4 & 5 & 6 & 7 & 8 & 9 & 10 & 11 \\
\hline Pomorskie & 49 & 3 & 7 & 1 & 1 & 2 & 2 & 10 & 23 & - \\
\hline Śląskie & 32 & 5 & 7 & 14 & - & 6 & - & - & - & - \\
\hline Świętokrzyskie & 69 & 24 & 5 & 7 & 6 & 3 & 5 & 7 & 11 & 1 \\
\hline $\begin{array}{l}\text { Warmińsko- } \\
\text {-mazurskie }\end{array}$ & 65 & 1 & 4 & 7 & 11 & 3 & 3 & 7 & 25 & 4 \\
\hline Wielkopolskie & 70 & 1 & 3 & 13 & - & 6 & - & - & 32 & 15 \\
\hline $\begin{array}{l}\text { Zachodniopo- } \\
\text { morskie }\end{array}$ & 95 & 12 & 14 & 5 & 2 & 2 & - & 15 & 37 & 8 \\
\hline
\end{tabular}

*Decyzje wydane na podstawie art. 29 oraz art. 40a ust. 1 pkt 4 ustawy z 2000 roku o jakości handlowej artykułów rolno-spożywczych.

Źródło: Opracowanie własne na podstawie IJHARS [2017b].

Najwięcej zafałszowań odnotowano w przypadku takich grup produktów, jak: mięso i przetwory mięsne, mąka i przetwory zbożowe oraz wyroby garmażeryjne, a także ryby i przetwory rybne. W przypadku kawy i herbaty, octu oraz czekolady i wyrobów czekoladowych inspektorzy IJHARS odnotowali najmniej uchybień związanych z zafałszowaniem (tab. 2).

Tabela 2

Liczba upublicznionych decyzji w latach 2009-2017 dotyczących zafałszowań artykułów rolno-spożywczych z uwzględnieniem grupy technologicznej*

\begin{tabular}{|c|c|c|c|c|c|c|c|c|c|c|}
\hline $\begin{array}{l}\text { Grupa } \\
\text { technologiczna }\end{array}$ & $\begin{array}{l}\frac{\varepsilon}{0} \\
\frac{0}{0} \\
0\end{array}$ & : & 응 & ז্ণ & $\stackrel{N}{\check{N}}$ & $\stackrel{m}{\grave{N}}$ & $\stackrel{+}{\grave{N}}$ & $\stackrel{n}{\stackrel{2}{\sim}}$ & $\frac{0}{2}$ & 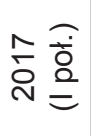 \\
\hline 1 & 2 & 3 & 4 & 5 & 6 & 7 & 8 & 9 & 10 & 11 \\
\hline $\begin{array}{l}\text { Mięso i przetwory } \\
\text { mięsne }\end{array}$ & 267 & 14 & 19 & 27 & 12 & 7 & 3 & 18 & 120 & 47 \\
\hline $\begin{array}{l}\text { Mąka i przetwory } \\
\text { zbożowe }\end{array}$ & 162 & 32 & 30 & 11 & 7 & 24 & 11 & 3 & 30 & 14 \\
\hline $\begin{array}{l}\text { Wyroby } \\
\text { garmażeryjne }\end{array}$ & 68 & 2 & 3 & 1 & 2 & 2 & 7 & 17 & 29 & 5 \\
\hline $\begin{array}{l}\text { Ryby i przetwory } \\
\text { rybne }\end{array}$ & 66 & 9 & 5 & 7 & 7 & 5 & 1 & 9 & 19 & 4 \\
\hline $\begin{array}{l}\text { Owoce, warzywa } \\
\text { i przetwory }\end{array}$ & 43 & 3 & 7 & 5 & 15 & - & 2 & 5 & 4 & 2 \\
\hline $\begin{array}{l}\text { Mleko i produkty } \\
\text { mleczne }\end{array}$ & 32 & 2 & 1 & - & 4 & 4 & 1 & 2 & 16 & 2 \\
\hline Napoje alkoholowe & 25 & 3 & 4 & 7 & 2 & - & 3 & 7 & 15 & 3 \\
\hline Wyroby cukiernicze & 24 & 2 & 7 & 3 & 2 & 1 & 1 & 3 & 4 & 1 \\
\hline
\end{tabular}


Tabela 2, cd.

\begin{tabular}{|l|c|c|c|c|c|c|c|c|c|c|}
\hline \multicolumn{1}{|c|}{1} & 2 & 3 & 4 & 5 & 6 & 7 & 8 & 9 & 10 & 11 \\
\hline $\begin{array}{l}\text { Napoje } \\
\text { bezalkoholowe }\end{array}$ & 21 & 3 & 2 & & 7 & 2 & 3 & 2 & 2 & - \\
\hline Jaja & 17 & - & 1 & 4 & 1 & 2 & - & 1 & 8 & - \\
\hline Przyprawy & 15 & - & 4 & 4 & 1 & 1 & 4 & - & 1 & - \\
\hline Miody & 14 & - & - & 6 & 2 & 3 & - & 2 & - & - \\
\hline Nasiona i orzechy & 9 & 1 & - & 4 & - & - & 1 & - & 3 & - \\
\hline $\begin{array}{l}\text { Koncentraty } \\
\text { spożywcze }\end{array}$ & 8 & - & 2 & - & - & 5 & - & 1 & - & - \\
\hline Oleje i tłuszcze & 7 & - & 2 & - & 2 & - & - & 1 & 2 & - \\
\hline $\begin{array}{l}\text { Czekolada i wyroby } \\
\text { czekoladowe }\end{array}$ & 4 & - & - & - & - & 1 & - & - & 3 & 1 \\
\hline Ocet & 3 & - & - & - & - & - & 2 & 1 & - & - \\
\hline Kawa i herbata & - & - & - & - & - & - & - & - & 3 & - \\
\hline
\end{tabular}

*Decyzje wydane na podstawie art. 29 oraz art. 40a ust. 1 pkt 4 ustawy z 2000 roku o jakości handlowej artykułów rolno-spożywczych.

Źródło: Opracowanie własne na podstawie IJHARS [2017b].

Wśród przyczyn zafałszowań upublicznionych decyzji pojawia się najczęściej aspekt ,wprowadzające w błąd informacje na temat składu produktu” (tab. 3).

\section{Tabela 3}

Przyczyny zafałszowania artykułów rolno-spożywczych w latach 2009-2017 (I poł.)

\begin{tabular}{|l|c|}
\hline Przyczyna zakwestionowania & Udział [\%] \\
\hline Wprowadzające w błąd informacje na temat składu produktu & 57,6 \\
\hline Wprowadzająca w błąd nazwa produktu & 18,9 \\
\hline Zafałszowanie w zakresie masy produktu & 6,0 \\
\hline $\begin{array}{l}\text { Niezgodna z prawdą data minimalnej trwałości/termin przydatności } \\
\text { do spożycia }\end{array}$ & 6,0 \\
\hline Wprowadzenie w błąd co do pochodzenia produktu & 2,2 \\
\hline Inne & 9,3 \\
\hline
\end{tabular}

*Decyzje wydane na podstawie art. 29 oraz art. 40a ust. 1 pkt 4 ustawy z 2000 roku o jakości handlowej artykułów rolno-spożywczych.

Źródło: Opracowanie własne na podstawie IJHARS [2017b].

W wyniku planowych kontroli jakości handlowej artykułów rolno-spożywczych przeprowadzonych na rynku krajowym w 2016 roku stwierdzono, że: $1,2 \%$ skontrolowanych partii artykułów rolno-spożywczych nie odpowiadała deklarowanym cechom organoleptycznym; 12,7\% skontrolowanych partii wyrobów zbadanych laboratoryjnie miało parametry fizykochemiczne niezgodne 
z przepisami o jakości handlowej lub z deklaracją producenta; 21,3\% skontrolowanych partii artykułów rolno-spożywczych było nieprawidłowo oznakowanych [IJHARS 2017a]. Jak podkreśla Kowalczyk [2014b], główne rodzaje nieprawidłowości są związane z kilkoma powtarzającymi się zjawiskami, takimi jak:

- zaniżanie zawartości najbardziej wartościowych składników (np. mięsa ryby w konserwach i marynatach rybnych),

- zastępowanie składników droższych tańszymi (np. tłuszczu mlecznego tłuszczem roślinnym w przetworach mlecznych, mięsa - MOM-em w przetworach mięsnych),

- nieujawnianie ważnych dla konsumenta składników małowartościowych lub wręcz niebezpiecznych dla zdrowia (np. alergenów),

- stosowanie niedozwolonych działań marketingowych mających na celu wykształcenie u klienta przeświadczenia o właściwościach lub cechach, których $\mathrm{w}$ istocie produkt nie ma (np. powoływanie się bez uzasadnienia na tradycyjne metody i receptury, deklarowanie braku dodatków, których i tak prawo zabrania dodawać - przykładowo konserwantów w koncentratach spożywczych i mrożonkach owocowych oraz warzywnych),

- podawanie w wykazie składników faktycznie niewystępujących w produkcie finalnym.

\section{Podsumowanie}

Konsument nieświadomy zafałszowań artykułu rolno-spożywczego nabywa go, najczęściej sugerując się deklaracjami umieszczonymi na opakowaniu i wierząc $w$ ich wiarygodność. $Z$ punktu ochrony konsumenta istotne jest więc, aby informacje zawarte w decyzjach dotyczących zafałszowań artykułów rolno-spożywczych były podawane do publicznej wiadomości. Dla producenta fałszującego produkty takie działanie pociąga za sobą znamienne skutki. Podanie do publicznej wiadomości nazwy producenta, który fałszuje produkty, może ograniczać w znacznym stopniu popyt nie tylko na te zafałszowane, ale na wszelkie artykuły przez niego wytwarzane. Utrata dobrej reputacji bywa dla przedsiębiorcy najczęściej bardziej dotkliwa niż kara pieniężna, a odbudowanie raz utraconego zaufania konsumenta jest najczęściej procesem niezwykle trudnym oraz długotrwałym. Jak wskazują wyniki działań kontrolnych, nadal istnieje potrzeba przeprowadzania kontroli w zakresie zafałszowań żywności przez organy urzędowej kontroli żywności w Polsce. Należy podkreślić również istotny aspekt, że działania dotyczące występowania zafałszowań na rynku żywności są prowadzone również w ramach sieci unijnej FFN, co przyczynia się do większej ochrony konsumentów na poziomie całej Unii Europejskiej. 


\section{Literatura}

Decyzja wykonawcza Komisji (UE) nr 2015/1918 z dnia 22 października 2015 r. ustanawiająca system pomocy i współpracy administracyjnej na podstawie rozporządzenia (WE) nr 882/2004 Parlamentu Europejskiego i Rady w sprawie kontroli urzędowych przeprowadzanych w celu sprawdzenia zgodności z prawem paszowym i żywnościowym oraz regułami dotyczącymi zdrowia zwierząt i dobrostanu zwierząt, Dz.Urz. UE L 280/31 z 24.10.2015.

European Commission, EC, 2017: The EU Food Fraud Network and the System for Administrative Assistance \& Food Fraud Annual Report 2016, https://ec.europa.eu/food/ sites/food/files/safety/docs/food-fraud_network_activity_report_2016.pdf [dostęp: 12.10.2017].

GUS, 2017: Sytuacja gospodarstw domowych w $2016 r$. w świetle wyników badania budżetów gospodarstw domowych. Notatka informacyjna, Warszawa, https://stat.gov.pl/obszarytematyczne/warunki-zycia/dochody-wydatki-i-warunki-zycia-ludnosci/sytuacja-gospodarstw-domowych-w-2016-r-w-swietle-wynikow-badania-budzetow-gospodarstw-domowych,3,16.html [dostęp: 12.10.2017].

IJHARS, 2017a: Sprawozdanie roczne 2016, Warszawa, http://www.ijhar-s.gov.pl/pliki/Apliki-z-glownego-katalogu/ethernet/2017/kwiecien/sprawozdanie $\% 202016$.pdf [dostęp: 12.10.2017].

IJHARS, 2017b: Zafałszowane artykuły rolno-spożywcze, http://www.ijhar-s.gov.pl/index. php/art-29.html [dostęp: 28.10.2017].

Konstytucja Rzeczypospolitej Polskiej z dnia 2 kwietnia 1997 r., Dz.U. 1997 nr 78, poz. 483, z późn. $z m$.

KOWALCZYK S., 2009: Globalizacja, agrobiznes i produkcja żywności, [w:] S. Kowalczyk (red.), Bezpieczeństwo żywności w erze globalizacji, Oficyna Wydawnicza SGH, Warszawa, 55.

KOWALCZYK S., 2014a: Prawo czystej żywności. Od Kodeksu Hammurabiego do Codex Alimentarius, Oficyna Wydawnicza SGH, Warszawa.

KOWALCZYK S., 2014b: Bezpieczeństwo i jakość polskiej żywności, Roczniki Naukowe Stowarzyszenia Ekonomistów Rolnictwa i Agrobiznesu 16 (4), 147-152.

PFPŻ ZP, 2017: Odbudowa zaufania do żywności. Prace punktu kontaktowego ds. oszustw żywnościowych, http://www.pfpz.pl/nowosci/?id_news=4432\&lang_id=1\# [dostęp: 12.10.2017].

Rozporządzenie (WE) nr 178/2002 Parlamentu Europejskiego i Rady (WE) z dnia 28 stycznia 2002 r. ustanawiające ogólne zasady i wymagania prawa żywnościowego, powołujące Europejski Urząd ds. Bezpieczeństwa Żywności oraz ustanawiające procedury w zakresie bezpieczeństwa żywności, Dz.U. UE L 31/1 z 01.02.2002.

Rozporządzenie Parlamentu Europejskiego i Rady (UE) nr 1169/2011 z dnia 25 października 2011 r. w sprawie przekazywania konsumentom informacji na temat żywności, zmiany rozporządzeń Parlamentu Europejskiego i Rady (WE) nr 1924/2006 i (WE) nr 1925/2006 oraz uchylenia dyrektywy Komisji 87/250/EWG, dyrektywy Rady 90/496/ /EWG, dyrektywy Komisji 1999/10/WE, dyrektywy 2000/13/WE Parlamentu Europej- 
skiego i Rady, dyrektyw Komisji 2002/67/WE i 2008/5/WE oraz rozporządzenia Komisji (WE) nr 608/2004, Dz.Urz. UE L 304/18 z 22.11.2011.

Rozporządzenie Parlamentu Europejskiego i Rady (UE) 2017/625 z dnia 15 marca 2017 r. w sprawie kontroli urzędowych i innych czynności urzędowych przeprowadzanych w celu zapewnienia stosowania prawa żywnościowego i paszowego oraz zasad dotyczących zdrowia i dobrostanu zwierząt, zdrowia roślin i środków ochrony roślin, zmieniające rozporządzenia Parlamentu Europejskiego i Rady (WE) nr 999/2001, (WE) nr 396/2005, (WE) nr 1069/2009, (WE) nr 1107/2009, (UE) nr 1151/2012, (UE) nr 652/2014, (UE) 2016/429 i (UE) 2016/2031, rozporządzenia Rady (WE) nr 1/2005 i (WE) nr 1099/2009 oraz dyrektywy Rady 98/58/WE, 1999/74/WE, 2007/43/WE, 2008/119/WE i 2008/120/WE, oraz uchylające rozporządzenia Parlamentu Europejskiego i Rady (WE) nr 854/2004 i (WE) nr 882/2004, dyrektywy Rady 89/608/EWG, 89/662/EWG, 90/425/EWG, 91/496/EWG, 96/23/WE, 96/93/WE i 97/78/WE oraz decyzję Rady 92/438/EWG (rozporządzenie w sprawie kontroli urzędowych), Dz.Urz. UE L 95/1 z 07.04.2017.

TARGOŃSKI Z., STÓJ A., 2005: Zafatszowania żywności i metody ich wykrywania, Żywność. Nauka. Technologia. Jakość 4 (45) [supl.], 30-40.

UOKiK, 2010: Informacja o zafatszowanych produktach żywnościowych wykrytych $w$ trakcie kontroli Inspekcji Handlowej w 2010 roku, Warszawa.

Ustawa z dnia 21 grudnia 2000 r. o jakości handlowej artykułów rolno-spożywczych, Dz.U. 2017, poz. 2212.

Ustawa z dnia 25 sierpnia 2006 r. o bezpieczeństwie żywności i żywienia, Dz.U. 2017, poz. 149 z późn. zm.

\section{Abstrakt}

Celem badań było przedstawienie regulacji prawnych dotyczących kwestii zafałszowań na rynku artykułów rolno-spożywczych oraz efektów działań IJHARS w tym zakresie. Badaniami objęto polskie i unijne regulacje prawne poruszające kwestię nieprawidłowości i odpowiedzialności przedsiębiorców na rynku żywności. Cel ten zrealizowano poprzez analizę danych wtórnych, tj. aktów prawnych oraz dostępnych wyników kontroli przeprowadzonych w latach 2009-2017 przez organy urzędowej kontroli żywności. Szczególną uwagę zwrócono na analizę decyzji administracyjnych wydanych przez IJHARS na podstawie art. 29 ustawy o jakości handlowej artykułów rolno-spożywczych, dotyczących zafałszowań artykułów rolno-spożywczych, które są upubliczniane na stronie internetowej inspekcji. Wyniki działań kontrolnych wskazują na zasadność prowadzenia dalszych działań kontrolnych, zwłaszcza w zakresie etykietowania żywności.

Słowa kluczowe: konsument żywności, zafałszowania żywności, artykuły rolno-spożywcze, urzędowa kontrola żywności 


\title{
The agricultural and food products adulteration in the eyes of the legal regulations and activities of the official food control authorities in Poland
}

\begin{abstract}
The aim of the research was to present legal regulations concerning adulteration on the market of agricultural and food products, and the effects of actions taken by IJHARS in this regard. The study has covered the Polish and EU legal regulations concerning the issues of irregularities and of the liability of entrepreneurs on the foodstuffs market. This goal has been achieved by analysing secondary data, i.e. legal acts and the available results of the inspections conducted in 2009-2017 by the official food control authorities. The administrative decisions issued by IJHARS pursuant to Article 29 of the Act on Merchantable Quality of Agricultural and Food Products, concerning the adulteration of agricultural and food products, which are published on the Inspection's website, have been analysed in particular detail. The results of the control activities indicate that further control activities are justified, in particular with regard to food labelling.
\end{abstract}

Key words: consumers of food, food adulteration, agricultural and food products, official food control authorities 
